\title{
Language attitude among Tamil language teachers
}

\author{
Kartheges Ponniah, Kingston Pal Thamburaj *, Sammikkanu Jabamoney Isak Samuvel
}

Faculty of Languages and Communication, Sultan Idris Education University, Perak, Malaysia

\section{A R T ICLE IN F O}

\section{Article history:}

Received 18 January 2017

Received in revised form

18 May 2017

Accepted 23 May 2017

\section{Keywords:}

Tamil

Language

Language teachers

\begin{abstract}
A B S T R A C T
The purpose of this paper is to find the language attitude among Tamil Language teachers. It explored the stereotyped impressions of Tamil language teachers towards Tamil language, which includes language learning, language choice and usage. The study was conducted on 42 Tamil language teachers around Kuala Lumpur and Tanjung Malim. The study incorporated mixed method. Paulston's theory was used to explain the reason for the attitudes. Results of the study showed sharp decline in the use of the Tamil language among the Kuala Lumpur teachers. Tanjung Malim teachers showed a little interest towards language maintenance. Demographical and social factors were identified to be the reason for the attitude. Overall finding showed that Tamil language teachers are experiencing language shift by adapting to English and Malay language.
\end{abstract}

(C) 2017 The Authors. Published by IASE. This is an open access article under the CC BY-NC-ND license (http://creativecommons.org/licenses/by-nc-nd/4.0/)

\section{Introduction}

Tamils who are the minority group (Gill, 2013) pay less attention to the regular use of Tamil language and show great interest in developing another language. They seem to be comfortable communicating in a language that is way too different from their root. The same situation can be seen among the educators.

Educators have a strong pertaining in developing a language. It is language that reflects the root of the identity of someone. However, it was observed that Tamil language teachers are not giving much attention to the maintenance of the Tamil language. Such attitude can cause gradual shift of Tamil language. Therefore the main purpose of this study is to analyze the reason for their language attitudes.

The core purpose of this study is to find the attitude of Tamil language teachers on their language preference.

The language attitude among Tamil language teachers is little known as there is less research focused on them. The present research aims to contribute to the filling of this knowledge gap. The research will help to identify the probable reasons for the language attitude of Tamil language teachers. It also helps to raise awareness on the state of their mother language. If language attitude revealed

\footnotetext{
* Corresponding Author.

Email Address: fkingston@gmail.com (K. P. Thamburaj) https://doi.org/10.21833/ijaas.2017.06.020

2313-626X/@ 2017 The Authors. Published by IASE.

This is an open access article under the CC BY-NC-ND license

(http://creativecommons.org/licenses/by-nc-nd/4.0/]
}

gradual shift, it can act as a wake- up call and enable them to take initiatives to maintain language.

Main question of this research is what the reasons for the language attitude of Tamil language teachers from Kuala Lumpur and Tanjung Malim are.

\section{Literature review}

Coming closer to the ethnic subgroup of Tamils, there have been researches on language shift and maintenance conducted among Malaysian Tamils such as Schiffman (1995), and David and Naji (2000). Schiffman (1995) found that less educated Malaysian Tamils maintain their mother tongue while well educated people prefer to use English language. He also stated that Muslim Tamils are exception in this case as they tend to embrace Malay language. So, hereby we can sum up that education and intermarriage acts as factors in determining choice of language. Schiffman (1995) has also concluded that Tamil is seen as a language with no economic value for Malaysian. The findings revealed the status of Tamil language in Malaysia. David and Naji (2000) on the other hand, studied the use of the mother tongue among Tamil undergraduates at a university and their families. A 25-item questionnaire was presented to 90 undergraduates and their families to determine the future of their mother tongue and to compare language choice and use between the older and younger respondents. Findings revealed that oldest age group uses Tamil language primarily, middle age group uses English and the younger generation speaks using the mixture of English, Tamil and Malay. They also add on that these 
undergraduates look English and Malay as a language that empowers them. Based on these two researches, it can be concluded that educators and younger generations tend to shift away from Tamil language.

\section{Methods}

\subsection{Participants}

For this research 42 key informants from 6 different schools located in Kuala Lumpur and Tanjung Malim were used. All the informants were language teachers teaching Tamil subjects for primary school students.

\subsection{Material}

Questionnaire and informal interview were used to collect the data to find the attitudes and perception of the Tamil language teachers.

1. Malay /English language is very necessary for survival in contemporary global community.

2. Do you think Malay or English proficiency ensures better economic security?

3. Can students develop a better understanding of modern scientific concepts in than Tamil language?

4. When you see a person speaking Malay or English, do you think that he or she is a learned, civilized and well-mannered person?

5. What, according to you, are the reasons of this shifting from Tamil language to Malay/ English language?

Based on the answer given, participant's attitudes and perceptions towards the Tamil language were identified.

\section{Data collection analysis}

This study explored the stereotyped impressions of Tamils towards Tamil language, which includes language learning, language choice and usage. Analysis on the attitude of the teachers in language learning revealed some information. The information was categorized into two aspects namely i) language acquisition and ii) language preference

\subsection{Language acquisition}

As a Malaysian and Tamil language teacher all the participants know the three main languages namely Tamil, Malay and English. Tamil being the mother tongue for most of the participants, Malay being the national language and English being the lingua franca emphasize the need of knowing these languages. But what differs here is the level of communicative language ability of each language known by the participants.
All the teachers from Tanjung Malim selected Tamil language as the first option for language learnt first followed by the other languages (Table 1). This shows the high level of communicative ability and confidence they have in Tamil language. Whereas, majority of the teachers from Kuala Lumpur preferred English and Malay as the languages learnt first. This clearly shows that teacher from urban area are exposed more to English and Malay language speaking environment.

Analysis on the language learnt to read and write is also done. In the context of this research, the orders of preference in writing the language learn first determine the language preference given by the respondents. All the teachers from Tanjung Malim and 15 teachers from Kuala Lumpur stated Tamil in the first place whereas, six teachers from Kuala Lumpur wrote other languages (Malay and English) in the first place. This shows that several teachers made other languages as their preference. Entertainment preference was also analyzed to the language acquisition of the participants.

\subsubsection{Entertainment}

Teachers from Kuala Lumpur show a great interest in having diverse language for entertainment purpose compared to teachers from Tanjong Malim. Tanjung Malim and Kuala Lumpur teachers claim that non-Tamil programs are quite exciting and help to improve their language vocabulary skills.

\subsubsection{Reading materials}

Majority of the teachers from Tanjung Malim read Tamil materials more on daily basis. The number of teachers reading non Tamil reading material is seems to be equal. Whereas teachers from Kuala Lumpur prefer to read more English reading materials compared to Tamil and Malay on daily basis. This clearly tells us that Kuala Lumpur teachers show a keen interest in reading non Tamil material every day.

\subsection{Language preference}

The findings on language preference were placed into three categories namely category a) Language proficiency level, b) Language usage and c) Language of Communication.

\subsubsection{Language proficiency level}

Tanjung Malim teachers have greater comprehension in Tamil language. Kuala Lumpur teachers have a strong understanding of English and Malay languages compared to Tamil language. Tanjung Malim teachers have excellent Tamil speaking skill compared to Kuala Lumpur teachers. Likewise Kuala Lumpur teachers excel in English speaking skill the most. Teachers from Tanjung 
Malim excel in Tamil writing skill compared to other two languages. Kuala Lumpur teachers have excellent multilingual skill compared to Tanjung Malim teachers.

Table 1: Language learnt first

\begin{tabular}{ccccc}
\hline \multirow{2}{*}{ Language Learnt First } & \multicolumn{4}{c}{ Number of respondents } \\
\cline { 2 - 5 } & \multicolumn{2}{c}{ Tanjung Malim } & \multicolumn{2}{c}{ Kuala Lumpur } \\
\cline { 2 - 5 } & No & $\%$ & No & $\%$ \\
\hline Tamil & 20 & 95.2 & 19 & 81 \\
$\begin{array}{c}\text { Other language (Telugu, } \\
\text { Malayalam, Malay, English) } \\
\text { Total }\end{array}$ & 1 & 4.8 & 2 & 19 \\
\hline
\end{tabular}

\subsubsection{Language use}

Tanjung Malim teachers always use Tamil language during school hours at maximum level. The frequency of the usage of other languages varies. Teachers from Kuala Lumpur also use Tamil language frequently at school. But a few teachers compliment the usage of English and Malay language. Teachers also need to communicate in Malay language since they have Malay staffs working in school administration.

\subsubsection{Language of communication}

Kuala Lumpur teachers are showing more inclination towards language shift as they prefer other languages with their children. This will certainly affect the following generation. This is because the attitude of minority group parents towards their heritage language will determine how effectively they transmit that language to their children. Teachers from Kuala Lumpur are more interested in learning and adapting Malay and English language, they have a positive attitude towards the multilingualism as they believe it will help them to attain their requirements to live in the multiracial society.

\section{Findings and discussion}

The underlying factors that have been identified were categorized into two main groups namely demography and social.

\subsection{Demographical factors}

The demographical factors that played important part in the language shift were a) age and b) gender middle age groups ranging from 25-44 are becoming dominant to the language shift since they showed more interest in learning and applying other languages. They are seemed to be exposed more to the multilingual environment. Gender also plays as one of the demographical factor that affects language shift. In the case of gender, it has been established that women tend to use fewer stigmatized forms than men, and in formal speech they are more sensitive to prestige language than men (Coates, 1998). This research also supports the statement above by indicating that females prefer of complimenting Malay and English language in their daily conversation compared to male respondents.

It was the female respondents who stated in interview that they want to communicate in a prestigious language and English does play its role well in that aspect. A respondent explained that "English has a lot to offer as it is a universal language. We gain respect in public when communicate in English. People look up to us" and there was another respondent who commented "that Tamil is not a high-class language; so, people opt for English instead". All the male teachers inclined more towards Tamil language. So, as a conclusion we can say that females are exposed more to language shift as they hold a dominant position in determining home language. This follows Paulston's theory which claims that language shift often begins with women (if access and opportunities to the dominant language are present). This is observable in their choice of code, in their choice of marriage partner and consequently in their choice of language to raise their children in (Van Aswegen, 2008).

\subsection{Social factors}

Motivation, easy communication, economic value, ethnic nationalism, social identity motivation, and the feel of pride were identified as social factors that contribute to the language attitude that one has for Tamil language and other languages.

\subsubsection{Motivation}

A number of teachers from Tanjung Malim showed a great interest of maintaining Tamil language but most of the teachers prefer other languages to be their home language. This was extensively seen among the teachers from Kuala Lumpur. A respondent answered that "Speaking English in public is prestigious. It shows the multilingual skill we possess". Most of them answered that it is better to have multilingual skills to set a standard among the public. Besides knowing mother tongue they state it is important to be able to converse in Malay which is the national language and English which is the lingua franca. This is shown in of the respond of an informant stating that "Malay language is important. It helps us economically". This shows that the respondents have their own attitude towards the language they are speaking.

As regards to attitude towards the English language, all the respondents reported a positive attitude towards English. When asked whether they will place English as their home language 4 of them reported affirmatively. They felt 'proud' to use the English language. In fact, they also said that they encouraged their children to use English always. Such a positive attitude towards English causes them to use it frequently which improves their language skills. The other two teachers felt that Tamil language should be given the first place.

While most of the respondents in the questionnaire reported positive attitudes towards 
the Tamil language, the majority of them 'do not feel it is necessary' to learn Tamil as its already known mother tongue. They even state that it is a waste of time to learn a language which is already known. One respondent claimed that "Tamil has given a way for English language in the economic world. So it is not necessary for us to hold tight to it. It is time for us to have a broader view and accept to indulge ourselves in the world of lingua franca".

Such a mixed set of views towards the mother tongue indicates an ongoing conflict between their linguistic identity and utility of the language, as an enabling factor, to survive in the multilingual world. The other three teachers stated that they use Tamil language more at home since it is closely linked to their linguistic identity. They stated that "As a Tamil it is important to know our mother tongue Tamil language". These teachers are from Tanjung Malim. Based on this, we can conclude that teachers from Kuala Lumpur shows more positive attitude towards the multilingualism environment.

Respondents from Kuala Lumpur answered that they are proud of their multilingual skills. They add that it put a high standard and perception of others on themselves. This proves the statement by Bradac (1990) who claimed "persons have attitudes toward language which are especially salient and influential in initial interactions (p. 387)". This means that various linguistic features trigger in message recipients beliefs ('Her way of talking leads me to think she is a professor') and evaluations ('She is intelligent') regarding message senders. The message sender refers to those who communicate in English and Malay. The message recipients refer to the society. So, it is clear that those with multilingual competence have prestigious position among the society.

They also said that multilingual skill increases their self-confidence and self-enthusiasms. Even though it can be viewed from positive side, but the perception they have on Tamil language was detrimental. One respondent said that "If you only focus on Tamil and ignore other languages, you are putting yourself at risk and depriving yourself of opportunities". They felt Tamil language has no economic value. Such a negative attitude is definitely detrimental to the language maintenance efforts and leads to quick erosion of language ability and the consequent shift.

Communication, economy, social identity and language power were identified as the motivation which stimulates the respondent's attitude towards the language shift.

\subsubsection{Eases communication}

When questioned further about the preference of using Malay and English language the respondents stated that it eases their communication. The neighborhood they are living which consists of multi-racial environment is one of the reasons for them to state so. This strongly supports the research of Karan (2011) whom states that individuals learn and use languages which they believe would best facilitate communication.

These finding strongly supports the theory on the community and the origin of the contact situation by Paulston. According to this theory, the course and speed of the language shift process is greatly influenced by the cause of the contact situation. Teachers from Kuala Lumpur are in frequent contact with a multi-racial community settled in various sections of town. So the communication and the language here will vary. Teachers have the need to communicate in English and Malay to have contact the people surrounding them. So, this in turn will increase the tendency to shift away from their mother tongue since contact situation requires them to do so. Finally it results in language shift.

\subsubsection{Economic value}

In this research a few respondents stated that Tamil language has no economic value. A respondent answered that "English and Malay is important in order to secure, sustain and improve our jobs, trades and networks that bring in profits". Other respondents also agreed by saying that they prefer to shift towards Malay and English language due to its economic value.

This economic motivation is evidenced in Malaysian language shift studies such as those on the shift to English by Hindu and Christian Malayalees (Nambiar, 2011), Tamil Iyers (Sankar, 2004), and Tamils (David and Naji, 2000). These studies have also been noted to use English in order to obtain jobs in the private sector (Leo and Abdullah, 2013). Schiffman (1995) also shows that the Tamils in Singapore and Malaysia are shifting from the Tamil language, which is seen as being of low economic value, to English as it is more economically viable.

\subsubsection{Ethnic nationalism}

Some respondents feel that becoming a part of Malay speaking community will increase their chance of receiving facilities provided by the government. They feel that whenever communicate fluently in Malay it helps to create a good perception on them from the officers of Malay community. They also stated that the movement of 1 Malaysia which is intended to bring all the races under one community can also be achieved since Malay language belongs to Malaysians of all races and not just the Malays. This would help inculcate a sense of belonging for all citizens irrespective of race.

This ethnic nationalism which drives them to learn and use other languages frequently has an undeniable intention that is to experience the social and economic facilities given. Paulston (1994) states that national movements must have a welldeveloped middle class. The driving force for ethnic nationalism will come from the middle class, whose privileges and power depend on the economic wellbeing of the nation. So in order to attain a place in 
society, they tend to perceive and apply languages that are economically strong.

\subsubsection{Social identity motivation}

3 respondents whose mother tongue is Telugu and Malayalam stated that they prefer to maintain their mother tongue. This means they have the mindset of complimenting the usage of their mother tongue more compared to Tamil language. One respondent stated that "We Malayaless prefer to use our mother tongue more with our family and relatives". This shows their preference to be identified as Malayalee and Telugu rather than Tamilian. This is known as social identity motivation. Social identity motivations relate to whether people want or do not want to be identified with a certain individual or group. They might also try to show solidarity with a group by adapting its language. Social identity motivations have played a key role in motivating them to use other languages more. Tamil language is only kept for educating purpose. Other than that, they are fond of multilingual environment. They speak Malay and English with their surroundings.

\subsubsection{Pride}

Lastly, majority of respondents feel that speaking other languages in public set a standard status on them. One respondent mentioned that "conversing in English opens the door of opportunities for social upgrade. It helps to develop the interaction with people in higher position". This follows the statement that people shift towards languages which they identify as having high prestige and thus they must use that language to gain power or prestige (Mafela, 2009). In the context of this research, respondents feel that being able to communicate in English and Malay make them to look more educated. The answer given by the respondents supports the research of Jameelah and Mohideen (2012) whom found that "The present generation, which is educated, feels that Tamil is of little importance and prefers to use Malay and English." Through this research most of the respondents think Tamil is not a high-class language and therefore opt for English instead.

\subsection{Attitude of language maintenance}

There are some teachers from Tanjung Malim who showed language maintenance more compared to Kuala Lumpur teachers. Reason for this language maintenance according to Paulston is the deliberate choice of language loyalty. Minority groups may see their language as a social resource or as a symbol in their fight for independence or whatever goal they are striving for. Thus, language loyalty is often an important aspect of nationalism that may have its own political status or the safeguarding of the social and cultural institutions of a group as its goal (Paulston, 1994).

A recent urge to send children to Tamil school and practice talking Tamil language more at home and public are the initiatives taken by these teachers to maintain Tamil language. This reflects the loyalty. Even some are seen to be loyal just to create a standard perception from the community they live. When one is intended to have all his needs fulfilled, and gain respect from the community and being protected within the community itself while leading a prestigious life he is said to be superior over his identity by emphasizing the importance of mother tongue. This is one of the important results which were obtained from this research through detailed observation.

\section{Conclusion}

In a nutshell, motivation to learn other language is found to be the primary reason for language shift to take place among the Tamil language teachers. Motivation to learn another language varies from person to person. Personal interests and understanding another culture are why most respondents desire to learn another language. In other words, people learn another language for personal reasons and purposes. The motivation is reflected in their attitude. This is what been observed in this research. Everybody has their own need and attitude towards the multilingualism environment. It was seem to favor them in many conditions.

\section{References}

Bradac JJ (1990). Language attitudes and impression formation. In: Giles $\mathrm{H}$ and Robinson WP (Eds.), Handbook of Language and Social Psychology: 387-412. John Wiley and Sons, Oxford, England.

Coates J (1998). Language and gender: A reader. Wiley-Blackwell, Hoboken, USA.

David MK and Naji I (2000). Do minorities have to abandon their languages: A case study of Malaysian Tamils. The International Scope Review, 2(3): 1-15.

Gill S (2013). Language policy challenges in multi-ethnic Malaysia. Springer Science and Business Media, Berlin, Germany.

Jameelah A and Mohideen M (2012). Language shift among Muslim Tamils in the Klang Valley. Department of Languages and Linguistics, University of Malaya, Kuala Lumpur, Malaysia.

Karan ME (2011). Understanding and forecasting ethnolinguistic vitality. Multilingual and Multicultural Development, 32(2): 137-149.

Leo AR and Abdullah AN (2013). Language choice and use of Malaysian Tamil Christian youths: A survey. Frontiers of Language and Teaching, 4: 149-166.

Mafela L (2009). Changing livelihoods, language use and language shift amongst Basarwa of Botswana. International Journal of Multilingualism, 6(3): 229-245.

Nambiar M (2011). The impact of language policy on language shifts in minority communities: Focus on the Malayalee community in Malaysia. In: Mukherjee D and David MK (eds.), National Language Planning and Language Shifts in Malaysian 
Minority Communities: Speaking in Many Tongues. IIAS/Amsterdam University Press, Amsterdam, Netherlands.

Paulston CB (1994). Linguistic minorities in multilingual settings: Implications for language policies. John Benjamins Publishing, Amsterdam, Netherlands.

Sankar L (2004). Language shift and maintenance among Tamil Iyers. Ph.D. Dissertation, Faculty of Languages and Linguistics University of Malaya, Kuala Lumpur, Malaysia.
Schiffman H (1995). Language shift in the Tamil communities of Malaysia and Singapore. Southwest Journal of Linguistics, 14(1): 151-165.

Van Aswegen JG (2008). Language maintenance and shift in Ethiopia: The case of Maale. Ph.D Dissertation, University of South Africa, Pretoria, South Africa. 